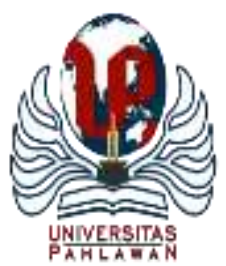

Edukatif : Jurnal Ilmu Pendidikan Volume 4 Nomor 1 Tahun 2022 Halm 1289 - 1298

EDUKATIF: JURNAL ILMU PENDIDIKAN

Research \& Learning in Education

https://edukatif.org/index.php/edukatif/index

\title{
Komponen-komponen Kurikulum Sekolah Dasar
}

\author{
Elfin Nazri ${ }^{1 凶}$, Azmar $^{2}$, Neliwati ${ }^{3}$ \\ Universitas Islam Negeri Sumatera Utara Medan, Indonesia ${ }^{1,2,3}$ \\ E-mail : nazrielfin301@ gmail.com ${ }^{1}, \underline{\text { azmarfandi@gmail.com }}^{2},{\underline{\text { neliwati@ } \text { uinsu.ac.id }^{3}}}^{3}$
}

\begin{abstract}
Abstrak
Pengembangan kurikulum dilakukan dengan proses analisis konteks yang berkaitan dengan tantangan internal maupun eksternal pendidikan. Penelitian ini bertujuan untuk mendeskripsikan komponen-komponen kurikulum di SD Negeri 165722 Kota Tebing Tinggi. Adapun fokus telaah dari komponen kurikulum tersebut, yaitu tujuan, isi/materi, proses pelaksanaan, dan evaluasi kurikulum. Adapun pendekatan penelitian yang digunakan adalah penelitian kualitatif dengan metode studi deskriptif. Hasil penelitian ini menunjukkan bahwa kurikulum sangat berpengaruh terhadap kualitas proses dan hasil pembelajaran peserta didik. Hal ini ditinjau dari berbagai komponen kurikulum, meliputi; tujuan, isi/materi (konten), proses pelaksanaan, dan evaluasi kurikulum di SD Negeri 165722 Kota Tebing Tinggi. Melalui penelitian ini, disimpulkan bahwa komponen-komponen kurikulum berfungsi sebagai acuan pembelajaran dan penentu arah pendidikan.
\end{abstract}

Kata Kunci: Komponen, Kurikulum, Pembelajaran.

Abstract

Curriculum development is carried out through a contextual analysis process related to the internal and external challenges of education. This study aims to describe the components of the curriculum at SD Negeri 165722 Tebing Tinggi City. As for the focus of the study of the curriculum components, namely objectives, content/material, implementation process, and curriculum evaluation. The research approach used is qualitative research with descriptive study methods. The results of this study indicate that the curriculum is very influential on the quality of the process and learning outcomes of students. This is viewed from various components of the curriculum, including; objectives, content/material (content), implementation process, and evaluation of the curriculum at SD Negeri 165722 Tebing Tinggi City. Through this research, it is concluded that the components of the curriculum function as a reference for learning and determine the direction of education.

Keywords: Components, Curriculum, Learning.

Copyright (c) 2022 Elfin Nazri, Azmar, Neliwati

$\triangle$ Corresponding author

Email : nazrielfin301@gmail.com

DOI $\quad:$ https://doi.org/10.31004/edukatif.v4i1.2160

ISSN 2656-8063 (Media Cetak)

ISSN 2656-8071 (Media Online) 


\section{PENDAHULUAN}

Sekolah Dasar merupakan jenjang pendidikan di tingkat dasar yang memberikan layanan di bidang pendidikan bagi peserta didik untuk membangun masa depannya (Trianingsih, 2016:197-211). Oleh karena itu, Sekolah Dasar selaku lembaga pendidikan perlu menyiapkan penyelenggaraan pendidikan yang berkualitas dan berkarakter sesuai amanat yang tertuang dalam Pasal 31 Undang-Undang Dasar 1945 (Syauqi, 2009). Ini menunjukkan fundamental dan urgennya pembenahan kualitas pendidikan sejak tingkat dasar.

Berbagai kebijakan pendidikan telah dikeluarkan oleh pemerintah sebagai upaya meningkatkan kualitas pendidikan di Indonesia sejak jenjang dasar (Sujatmoko, 2016: 181-212). Lebih lanjut, Rasyidi (2019:33-50) mengistilahkannya sebagai bagian dinamika dan inovasi dalam dunia pendidikan di Indonesia agar survive dan adaptif terhadap perkembangan zaman dan kecanggihan teknologi. Berkaitan dengan ini, Muslimin (2016:43-61) menjelaskan bahwa kebijakan yang paling sering mengalami perubahan dalam pendidikan yaitu dari aspek kurikulum. Lebih lanjut, Fatimah (2021:16-30) menyebutnya sebagai upaya pengembangan kurikulum, bukan sekadar mengganti kebijakan yang telah ada.

Sejatinya, perubahan kebijakan kurikulum adalah upaya pemerintah dalam rangka menjawab tantangan global dari keadaan dunia (Sudrajat, et.al., 2020:339-347). Untuk itu, pengelolaan pendidikan yang diharapkan dapat memenuhi kebutuhan dan kondisi daerah, harus segera dilaksanakan. Bentuk nyata desentralisasi pengelolaan pendidikan adalah diberikannya kewenangan kepada satuan pendidikan untuk mengambil keputusan berkenaan dengan pengelolaan pendidikan, seperti dalam pengelolaan kurikulum, baik dalam penyusunan maupun pelaksanaannya pada satuan pendidikan (Kuswandi, 2011:69-98). Sebagaimana diketahui bahwa kurikulum merupakan salah satu unsur yang memberikan kontribusi untuk mewujudkan proses berkembangnya kualitas potensi peserta didik tersebut.

Secara khusus, kurikulum dimaknai sebagai seperangkat rencana dan pengaturan mengenai tujuan, isi, dan bahan pelajaran serta cara yang digunakan sebagai pedoman penyelenggaraan kegiatan pembelajaran untuk mencapai tujuan pendidikan tertentu (Sidik, 2020). Tujuan tertentu ini meliputi tujuan pendidikan nasional serta kesesuaian dengan kekhasan, kondisi dan potensi daerah, satuan pendidikan, kompetensi lulusan dan peserta didik.

Secara operasional, kurikulum SD merupakan salah satu bentuk realisasi kebijakan desentralisasi dengan kebutuhan pengembangan agar kurikulum benar-benar sesuai dengan kebutuhan pengembangan potensi peserta didik di sekolah yang bersangkutan di masa sekarang dan yang akan datang, dengan mempertimbangkan kearifan lokal dan global, serta disesuaikan dengan tuntutan maupun strategi manajemen berbasis sekolah (Nuraini, 2019).

Pengembangan Kurikulum pada tahun pelajaran 2021/2022, merupakan langkah lanjutan Pengembangan Kurikulum KTSP 2006 dan Kurikulum 2013 yang mencakup kompetensi sikap, pengetahuan, dan keterampilan secara terpadu serta mengacu pada kurikulum yang dikembangkan pada tingkat nasional dan daerah (Mimin, 2021: 374-388). Sejalan dengan kebijakan tersebut, selanjutnya layanan kepada setiap jenjang kelas yang merujuk pada kebijakan pemerintah. Sementara itu, yang berkaitan dengan implementasi kurikulum diterapkan sesuai dengan mekanisme dan tata kelola masing-masing kurikulum baik yang versi kurikulum 2006 maupun 2013.

Tim Pengembang Kurikulum mengembangkan kurikulum dengan melihat beberapa analisis konteks yang berkenaan dengan tantang internal maupun eksternal (Suja, 2017: 77-93). Tantangan internal yang berkaitan dengan Tuntutan pendidikan yang mengacu kepada 8 Standar Nasional Pendidikan yang meliputi standar pengelolaan, standar biaya, standar sarana prasarana, standar pendidik dan tenaga kependidikan, standar isi, standar proses, standar penilaian, dan standar kompetensi lulusan. Sedangkan tantang eksternal yang berkaitan dengan Globalisasi: WTO, ASEAN Community, APEC, CAFTA, masalah lingkungan hidup, kemajuan teknologi informasi, konvergensi ilmu dan teknologi, Ekonomi berbasis pengetahuan dan budaya, pengaruh dan imbas teknosains, mutu, investasi dan transformasi pada sektor pendidikan. Atas dasar hal-hal 
tersebut Tim Pengembang Kurikulum menyusun kurikulum sekolah secara proposional untuk dijadikan pedoman dan arah penyelenggaraan pendidikan secara formal.

Sejatinya, penelitian relevan tentang komponen kurikulum pada satuan lembaga pendidikan telah dikaji secara luas oleh berbagai kalangan peneliti. Di antaranya membahas dari aspek pendidikan berbasis muatan lokal (Marliana \& Hikmah, 2013), pengembangan komponen kurikulum berbasis multikultural (Mansur, 2016; Alfarisi, 2020), desain dan model pengembangan kurikulum (Achruh, 2019:1-9), konsep dasar dan filosofi kurikulum pendidikan (Subhi, 2016:117-134), serta teori dan praktik komponen kurikulum pendidikan (Budianto, 2018:151-165).

Mencermati literature review di atas, diketahui bahwa kajian komponen kurikulum banyak diteliti dari ranah perubahan kebijakan dan upaya pengembangan kurikulum sebagai acuan pembelajaran. Sebagai pembeda, penelitian ini berupaya mengkaji khusus dari aspek komponen kurikulum pembelajaran di jenjang sekolah dasar, mengingat ini adalah tingkat utama pendidikan formal. Gap analysis lainnya yaitu pendalaman materi penelitian meliputi tujuan, isi/materi, proses pelaksanaan dan evaluasi kurikulum di SD tersebut, yang terangkum dalam judul, “Komponen-Komponen Kurikulum SD Negeri 165722 Kota Tebing Tinggi”.

\section{METODE PENELITIAN}

Penelitian ini menggunakan pendekatan kualitatif dengan metode studi deskriptif (Assingkily, 2021). Fokus penelitian berkaitan dengan komponen-komponen kurikulum pembelajaran, meliputi tujuan (orientasi pembelajaran), isi/materi, proses pelaksanaan pembelajaran, dan evaluasi kurikulum. Penelitian ini dilaksanakan di SD Negeri 165722 Kota Tebing Tinggi, beralamat di Jalan Asrama Kodim, Persiakan, Kec. Padang Hulu, Kota Tebing Tinggi, Provinsi Sumatera Utara. Pemerolehan data menggunakan teknik wawancara, observasi dan dokumentasi. Selama proses wawancara, peneliti bertindak sebagai pendengar dengan harapan informan lebih banyak menguraikan data yang diperlukan. Di samping itu, observasi partisipan yang dilaksanakan tidak serta merta menunjukkan identitas peneliti kepada informan, melainkan layaknya bergabung sebagai "warga sekolah" sehingga meminimalisir terjadinya rekayasa latar penelitian. Selanjutnya, data dianalisa menggunakan teknik reduksi data, penyajian data, dan penarikan kesimpulan. Akhirnya, keabsahan suatu data diperoleh melalui uji teknik triangulasi data, mulai dari aspek metode hingga sumber data penelitian.

\section{HASIL DAN PEMBAHASAN PENELITIAN}

\section{Tujuan Pembelajaran dalam Kurikulum Pendidikan}

Kurikulum merupakan seperangkat pembelajaran yang harus ditempuh dalam proses pembelajaran untuk menjadi acuan sekaligus orientasi pendidikan (Nidawati, 2021:22-42). Menurut Hasan (2013:163-178), terdapat empat dimensi makna dalam mendefinisikan kurikulum, yaitu (1) kurikulum sebagai suatu ide/gagasan; (2) kurikulum sebagai suatu rencana tertulis yang sebenarnya merupakan perwujudan dari kurikulum suatu ide; (3) kurikulum sebagai suatu kegiatan yang sering pula disebut istilah kurikulum sebagai suatu realita atau implementasi kurikulum. Secara teoritis, dimensi kurikulum ini adalah pelaksanaan dari kurikulum sebagai suatu rencana tertulis; (4) kurikulum sebagai suatu hasil yang merupakan konsekuensi sebagai suatu kegiatan.

Lebih lanjut, kurikulum sebagai salah satu komponen penting pendidikan, berperan sebagai orientasi atau arah semua kegiatan pembelajaran melalui perangkat (media, pendekatan, teknik, metode, model dan strategi) sehingga tercapai tujuan pembelajaran. Hal ini didasarkan pada perkembangan zaman, tuntutan atas kondisi dan kebutuhan masyarakat, serta menjalankan amanat UUD 1945 dalam mencerdaskan kehidupan bangsa Indonesia (Arifin, 2012). 
Secara umum, perubahan yang terdapat dalam kurikulum pendidikan di Indonesia mengacu pada tujuan pendidikan nasional. Tentu, perubahan yang dimaksud mengacu pada sistem nilai Pancasila yang berfungsi mengembangkan kemampuan dan bentuk watak serta peradaban bangsa yang bermatabat dalam rangka mencerdaskan kehidupan bangsa, bertujuan untuk berkembangnya potensi peserta didik, agar menjadi manusia yang beriman dan bertaqwa kepada Tuhan Yang Maha Esa, berakhlak mulia, sehat, berilmu, cakap, kreatif, mandiri, dan menjadi warga Negara yang demokratis serta bertanggung jawab. Tujuan pendidikan nasional merupakan tujuan jangka panjang yang menjadi dasar dari segala tujaun pendidikan nasioanl baik pendidikan formal, informal, maupun pendidikan nonformal (Hasan, 2004:1-9).

Tujuan Institusional adalah tujuan yang harus dicapai oleh setiap lembaga pendidikan. Tujuan institusional merupakan tujuan antara untuk mencapai tujuan umum yang dirumuskan dalam bentuk kompetensi lulusan setiap jenjang pendidikan dasar, menengah, kejuruan, dan jenjang pendidikan tinggi. Tujuan Kurikuler adalah tujuan yang harus dicapai oleh setiap bidang studi atau mata pelajaran. Tujuan kurikuler juga pada dasarnya merupakan tujuan anatar untuk mencapai tujuan lembaga pendidikan (Muzdalifah, 2020). Dengan demikian, setiap tujuan kurikuler harus dapat mendukung dan diarahkan untuk mencapai tujuan institusional.

Tujuan Pembelajaran yang merupakan bagian dari tujuan kurikuler, dapat didefinisikan sebagai kemampuan yang harus dimiliki oleh peserta didik setelah mereka mempelajari materi pelajaran tertentu dalam mata pelajaran tertentu dalam satu kali pertemuan. Karena hanya guru yang memahami kondisi lapangan, termasuk memahami karakteristik pesrta didik yang akan melakukan pembelajaran disuatu sekolah atu madrasah, maka menjabarkan tujuan pembelajaran adalah tugas guru (Hidayat, 2013).

Tujuan dari pengembangan kurikulum di SD Negeri 165722 Kota Tebing Tinggi adalah sebagai berikut: Pertama, Sebagai perangkat rencana dan pengaturan mengenai tujuan, isi, dan bahan pelajaran serta cara yang digunakan sebagai pedoman bagi sekolah dalam menyelenggarakan kegiatan pembelajaran sehingga siswa memiliki kesempatan belajar untuk mengembangkan seluruh potensi yang dimiliki oleh siswa untuk dapat menguasai kompetensi-kompetensi yang ada pada seluruh mata pelajaran melalui pembelajaran yang aktif, kreatif, efektif, dan menyenangkan.

Kedua, Sebagai dokumen tertulis yang dapat dijadikan acuan bagi pendidik dan tenaga kependidikan dalam mengembangkan kompetensi siswa sesuai dengan potensi daerah dan sumber daya yang dimiliki. Ketiga, Sebagai acuan belajar siswa dalam menerapkan ajaran agama berdasarkan keimanan dan ketakwaan, mengembangkan diri berdasarkan ilmu dan pengalaman yang diperoleh, dan hidup rukun berdasarkan nilainilai sosial yang berkembang di masyarakat. Keempat, Sebagai acuan bagi sekolah dalam membangun dan mengembangkan budaya dan karakter bangsa dalam kegiatan sekolah. Kelima, Sebagai acuan pendidikan dalam memberikan layanan kepada masyarakat sesuai dengan potensi sekolah dan sumber daya yang dimiliki.

\section{Isi/Materi Kurikulum}

Isi program kurikulum atau bahan ajar adalah segala sesuatu yang ditawarkan kepada siswa sebagai pelajar dalam kegiatan pembelajaran untuk mencapai tujuan. Isi kurikulum meliputi mata-mata pelajaran yang harus dipelajari siswa dan isi program masing-masing pelajaran tersebut. Jenis-jenis mata pelajaran ditentukan atas dasar institusional atau tujuan pendidikan tingkat satuan pendidikan (sekolah, madrasah, pondok pesantren dan lembaga pendidikan lain yang bersangkutan).

Mata pelajaran yang berisi materi-materi pokok dan program yang ditawarkan kepada siswa untuk dipelajari pada hakekatnya adalah isi kurikulum atau adapula yang menyebutnya dengan silabus. Dalam silabus terdapat tujuan kurikuler (standar kompetensi), tujuan pembelajaran (kompetensi dasar), indikator dan materi pokok atau pembelajaran di kelas oleh guru. Penentuan pokok-pokok bahasan atau materi pokok didasarkan atas standar kompetensi dan kompetensi dasar atau indikator.

Kriteria yang dapat membantu pada perencanaan kurikulum dalam menetukan isi metri ajar atau isi kurikulum antara lain: (1) Isi kurikulum harus sesuai, tepat dan bermakna bagi perkembangan siswa; (2) Isi 
kurikulum harus mencerminkan kenyataan sosial; (3) Isi kurikulum harus mengandung pengetahuan ilmiah yang tahan uji; dan (4) Isi kurikulum dapat menunjang tercapainya tujuan pendidikan (Suhanda \& Budiningsih, 2013:175-189).

Struktur dan Muatan Kurikulum pada jenjang pendidikan dasar yang dilaksanakan di SD Negeri 165722 Dinas Kota Tebing Tinggi khususnya kelas III dan VI menggunakan pedoman pada Peraturan Menteri Pendidikan Nasional Nomor 22 tahun 2006 tentang Standar Isi untuk Satuan Pendidikan Dasar Dan Menengah, yaitu meliputi lima kelompok mata pelajaran sebagai berikut; (1) Kelompok mata pelajaran agama dan akhlak mulia; (2) Kelompok mata pelajaran kewarganegaraan dan kepribadian; (3) Kelompok mata pelajaran ilmu pengetahuan dan teknologi; (4) Kelompok mata pelajaran estetika; (5) Kelompok mata pelajaran jasmani, olahraga dan kesehatan; dan (6) Muatan Lokal. Muatan Lokal di SD Negeri 165722 Kota Tebing Tinggi tahun pelajaran 2021/ 2022 terdiri dari 3 mata pelajaran yaitu: bahasa Jawa, baca tulis alQur'an, dan bahasa Inggris.

\section{Proses Pelaksanaan Kurikulum}

Proses pelaksanaan kurikulum harus menunjukkan adanya kegiatan pembelajaran, yaitu upaya guru untuk pembelajaran peserta didik, baik di sekolah melalui pembelajaran tatap muka, maupun di luar sekolah melalaui kegiatan terstruktur dan mandiri. Dalam konteks inilah, guru dituntut untuk menggunakan berbagai strategi pembelajaran, metode mengajar, media mengajar, media pembelajaran dan sumber-sumber belajar. Pemilihan strategi pembelajaran harus disesuaikan dengan tujuan kurikulum (SK atau KD), karakteristik materi pembelajaran, dan tingkat perkembangan peserta didik. Ada beberapa strategi pembelajaran yang dapat digunakan guru dalam menyampaikan isi kurikulum, antara lain; pertama, Strategi eksposetori klasikal; kedua, Strategi pembelajaran heuristik (discovery dan inquiry); ketiga, Strategi pembelajaran kelompok kecil; dan keempat, Strategi pembelajaran individual.

Beban belajar yang digunakan pada kelas III dan VI mengacu pada Peraturan Menteri Pendidikan Nasional Nomor: 22 tahun 2006 tentang Standar Isi untuk Satuan Pendidikan Dasar dan Menengah dengan rincian sebagai berikut:

1) Sistem yang Digunakan

- Beban belajar digunakan oleh adalah sistem di SD Negeri 165722 Kota Tebing Tinggi sesuai dengan Standar Isi.

- Jam pembelajaran untuk setiap mata pelajaran pada sistem paket dialokasikan sebagaimana tertera dalam struktur kurikulum yaitu 35 menit setiap jam pelajarannya.. Pengaturan alokasi waktu untuk setiap mata pelajaran yang terdapat pada semester ganjil dan genap dalam satu tahun ajaran dapat dilakukan secara fleksibel dengan jumlah beban belajar yang tetap. Jam tambahan yang diperbolehkan dalam Standar Isi yaitu 4 jam pelajaran digunakan untuk alokasi waktu mata pelajaran Muatan Lokal yaitu BTQ dan Bahasa Inggris.

2) Waktu Tatap Muka

- Dalam satu minggu masing-masing kelas mempunyai jumlah jam pelajaran sesuai struktur kurikulum ditambah 4 jam yang dialokasikan untuk muatan lokal Kabupaten (2 jam) dan bahasa Inggris ( 2 jam).

- Setiap hari sekolah masuk pukul 07.00 dan waktu pulang menyesuaikan jumlah jam pelajaran tiap harinya.

\section{3) Untuk kelas I, II, IV dan V}

Beban belajar untuk kelas I, II, IV dan V Peraturan Menteri Pendidikan dan Kebudayaan nomor 67 tahun 2013 tentang Kerangka Dasar dan Struktur Kurikulum Sekolah Dasar/Madrasah. Beban belajar merupakan keseluruhan kegiatan yang harus diikuti peserta didik dalam satu minggu, satu semester, dan satu tahun pembelajaran. 
a) Beban belajar di Sekolah Dasar/Madrasah Ibtidaiyah dinyatakan dalam jam pembelajaran per minggu.

b) Beban belajar satu minggu Kelas I adalah 30 jam pembelajaran.

c) Beban belajar satu minggu Kelas II adalah 32 jam pembelajaran.

d) Beban belajar satu minggu Kelas IV dan V adalah 36 jam pembelajaran.

e) Durasi setiap satu jam pembelajaran adalah 35 menit.

Beban belajar di Kelas I, II, IV, dan V dalam satu semester paling sedikit 18 minggu dan paling banyak 20 minggu.

\section{Evaluasi Kurikulum}

Evaluasi kurikulum merupakan komponen untuk melihat efektivitas pencapaian tujuan. Dalam konteks kurikulum, evaluasi dapat berfungsi untuk mengetahui apakah tujuan yang ditetapkan telah tercapai atau belum dan digunakan sebagai umpan balik dalam perbaikan strategi yang ditetapkan. Dengan evaluasi dapat diperoleh informasi yang akurat tentang pelaksanaan pembelajaran, keberhasilan siswa, guru, dan proses pembelajaran. Berdasarkan hasil evaluasi dapat dibuat keputusan kurikulum itu sendiri, pembelajaran, kesulitan, dan upaya bimbingan yang diperlukan.

Berikut diuraikan evaluasi kurikulum di SD Negeri 165722 Kota Tebing Tinggi berkaitan dengan Kenaikan Kelas dan Kelulusan, sebagai berikut:

1) Kenaikan Kelas untuk kelas III dan VI

- Kenaikan kelas ditetapkan berdasarkan hasil belajar siswa selama 1 tahun pelajaran.

- Siswa dinyatakan Naik Kelas apabila memenuhi syarat-syarat sebagai berikut:

$>\quad$ Memiliki Akhlak dan budi pekerti yang baik.

$>\quad$ Kehadiran minimal $85 \%$.

$>\quad$ Jumlah mata pelajaran yang tidak tuntas paling banyak 4 (empat) mata pelajaran.

- Bagi siswa yang tidak naik kelas disarankan untuk mengulang pada tahun ajaran berikutnya di kelas yang sama.

2) Kenaikan Kelas untuk kelas I, II, IV dan V:

- Menyelesaikan seluruh program pembelajaran dalam dua semester pada tahun pelajaran yang diikuti.

- Mencapai tingkat kompetensi yang dipersyaratkan, minimal sama dengan KKM.

- Mencapai nilai sikap untuk semua mata pelajaran minimal baik.

- Tidak terdapat nilai kurang dari KKM maksimal pada tiga mata pelajaran.

- Ketidakhadiran siswa tanpa keterangan maksimal $15 \%$ dari jumlah hari efektif.

\section{Evaluasi Hasil Pembelajaran}

Untuk menilai keberhasilan penguasaan siswa atau tujuan-tujuan khusus yang telah ditentukan, penting diadakan suatu evaluasi. Evaluasi ini disebut juga evaluasi hasil pembelajaran. Dalam evaluasi ini disusun butir-butir soal untuk mengukur pencapaian setiap tujuan yang khusus atau indikator yang telah ditentukan. Menurut lingkup luas bahan dan jarak waktu belajar dibedakan atau evaluasi formatif dan sumatif.

\begin{tabular}{|l|l|c|c|c|}
\hline \multirow{2}{*}{ No } & \multirow{2}{*}{ Mata Pelajaran } & \multicolumn{2}{|c|}{ Kriteria Ketuntasan Minimal } & \multirow{2}{*}{ Ket } \\
\cline { 3 - 4 } & & III & VI & \multirow{2}{*}{} \\
\hline 1 & Pendidikan Agama & 75 & 75 & \\
\hline 2 & Pendidikan Kewarganegaraan & 65 & 65 & \\
\hline 3 & Bahasa Indonesia & 75 & 75 & \\
\hline 4 & Matematika & 65 & 65 & \\
\hline 5 & Ilmu Pengetahuan Alam & 75 & 75 & \\
\hline 6 & Ilmu Pengetahuan Sosial & 65 & 65 & \\
\hline
\end{tabular}




\begin{tabular}{|l|l|c|c|c|}
\hline 7 & Seni Budaya dan Keterampilan & 65 & 65 & \\
\hline 8 & $\begin{array}{l}\text { Pendidikan Jasmani, Olahraga } \\
\text { dan Kesehatan }\end{array}$ & 70 & 75 & \multicolumn{2}{|l|}{} \\
\hline 9 & Mulok: & \multicolumn{4}{|l|}{} \\
\hline & a. Bahasa Jawa & 65 & 65 & \\
\hline & b. BTQ & 75 & 75 & \\
\hline & c. Bahasa Inggris & - & 65 & \\
\hline
\end{tabular}

Evaluasi formatif ditujukan untuk menilai penguasaan siswa terhadap tujuan-tujuan pembelajaran dalam jangka waktu yang relatif pendek. Tujuan utama dari evaluasi formatif sebenarnya lebih besar ditujukan untuk menilai proses pembelajaran. Evaluasi sumatif ditujukan untuk menilai penguasaan siswa terhadap tujuan-tujuan/kompetensi yang lebih luas, sebagai hasil usaha belajar dalam jangkan waktu yang cukup lama, satu semester, satu tahun/selama jenjang pendidikan. Evaluasi sumatif mempunyai fungsi yang lebih luas daripada evaluasi formatif.

\section{Evaluasi Pelaksanaan Pembelajaran}

Komponen yang dievaluasi dalam pembelajaran bukan hanya hasil belajar tetapi keseluruhan pelaksanaan pembelajaran, meliputi evaluasi komponen tujuan pembelajaran, materi pelajaran, strategi atau metode pembelajaran serta komponen pembelajaran itu sendiri. Stufflebeam, et.al., menggunakan model CIPP. Model evaluasi ini paling banyak diikuti oleh para evaluator, karena model evaluais ini lebih komprehensif jika dibandingkan dengan evaluasi lainnya.

Model CIPP orientasi pada suatu keputuasan (a decision oriented evaluation approach structured). Tujuannya adalah untuk membantu administrator (kepala sekolah dan guru) di dalam membuat keputusan. Berikut ini akan dibahas komponen atau dimensi model CIPP yang meliputi: context, input, process, product.

a. Evaluasi Konteks

Tujuan evaluasi konteks yang pertama adalah untuk mengetahui kekuatan dan kelemahan yang dimiliki. Kemudian, untuk mengetahui kekuatan dan kelemahan, evaluator akan dapat memberikan arah perbaikan yang diperlukan. Suharsimi \& Cepi Safrudin menjelaskan bahwa, evaluasi konteks adalah upaya menggambarkan dan merinci lingkungan kebutuhan yang tidak terpenuhi, populasi dan sampel yang dilayani, dan tujuan proyek.

b. Evaluasi Masukan

Tahap kedua dari model CIPP adalah evaluasi input, atau evaluasi masukan. Evaluasi masukan membantu mengatur keputusan, menentukan sumber-sumber yang ada, alternatif yang diambil, apa rencana dan strategi untuk mencapai tujuan, dan bagaimana prosedur kerja untuk mencapainya. Komponen evaluasi masukan meliputi: (1) Sumber daya manusia, (2) Sarana dan peralatan pendukung, (3) Dana atau anggaran, dan (4) Berbagai prosedur dan aturan yang diperlukan. Menurut Stufflebeam, pertanyaan yang berkenaan dengan masukan mengarah pada pemecahan masalah yang mendorong diselenggarakannnya program yang bersangkutan.

c. Evaluasi Proses

Evaluasi proses digunakan untuk mendeteksi rancangan prosedur selama tahap implementasi, menyediakan informasi untuk keputusan program dan sebagai rekaman yang telah terjadi. Evaluasi proses meliputi koleksi data penilaian yang telah ditentukan dalam praktik pelaksanaan program.

d. Evaluasi hasil

Dari evaluasi proses diharapkan dapat membantu pimpinan proyek atau guru untuk membuat keputusan yang berkenaan dengan kelanjutan, akhir, dan modifikasi program. Sementara itu, Farida Yusuf menjelaskan bahwa evaluasi produk untuk membantu keputusan selanjutnya, baik mengenai hasil yang telah dicapai maupun apa yang dilakukan setelah program itu berjalan. 
Dari pendapat di atas, dapat dipahami bahwa evaluasi produk sebagai salah satu komponen dari model CIPP berfungsi sebagai upaya mengecek ketercapaian dari suatu program (Gunawan, 2011). Lebih lanjut, Bhakti (2017:75-82) menjelaskan bahwa upaya evaluatif ini dapat juga membantu peningkatan grafik performa akademik pada satuan lembaga pendidikan. Bahkan, Suardipa \& Primayana (2020) menegaskan peran desain evaluasi program pembelajaran berpengaruh terhadap kualitas pembelajaran. Dengan demikian, pembelajaran yang telah diprogramkan dapat terlaksana dengan efektif, kreatif, dan menyenangkan (Gunadi, 2014:1-8).

\section{KESIMPULAN}

Hasil penelitian menunjukkan bahwa Implementasi reward yang diterapkan di MTs Qur'an Kisaran berupa penghargaan finansial seperti tunjangan, insentif, dan bonus. Penghargaan non-finansial seperti piagam, plakat sebagai pengakuan, dan promosi jabatan. Sedangkan untuk Implementasi punishment atau hukuman berupa peringatan, teguran, pemotongan gaji, pengurangan beban kerja, pergantian amanah jabatan, hingga pemutusan hubungan kontrak kerja antara guru dengan madrasah. Hasil setelah di Implementasikannya reward dan punishment ini menghasilkan nilai positif, yakni meningkatnya kinerja guru dilihat dari menurunnya persentase kinerja belum baik, dari $36 \%$ menjadi $9,4 \%$.

\section{DAFTAR PUSTAKA}

Achruh, A. 2019. Komponen Dan Model Pengembangan Kurikulum. Jurnal Inspiratif Pendidikan, 8(1), 1-9. Http://Journal.Uin-Alauddin.Ac.Id/Index.Php/Inspiratif-Pendidikan/Article/View/9933.

Alfarisi, S. 2020. Analisis Pengembangan Komponen Kurikulum Pendidikan Islam Di Madrasah Diniyah. Rayah Al-Islam, 4(2), 347-367. Https://Ejournal.Arraayah.Ac.Id/Index.Php/Rais/Article/View/346.

Arifin, Z. 2012. Komponen Dan Organisasi Kurikulum. Bandung: PT. Remaja Rosdakarya.

Assingkily, M.S. 2021. Metode Penelitian Pendidikan. Yogyakarta: K-Media.

Bhakti, Y.B. 2017. Evaluasi Program Model CIPP Pada Proses Pembelajaran IPA. JIPFRI (Jurnal Inovasi $\begin{array}{lllll}\text { Pendidikan Fisika Dan } & \text { Riset }\end{array}$ Http://Www.Journal.Stkipnurulhuda.Ac.Id/Index.Php/JIPFRI/Article/View/109.

Budianto, N. 2018. Komponen Kurikulum Pendidikan Agama Islam (PAI): Antara Teori Dan Praktik. Falasifa: Jurnal Studi Keislaman, Http://Ejournal.Inaifas.Ac.Id/Index.Php/Falasifa/Article/View/129.

Fatimah, I.F. 2021. Strategi Inovasi Kurikulum. Edutech: Jurnal Edukasi Dan Teknologi Pembelajaran, 2(1), 16-30. Https://Ejurnal.Umri.Ac.Id/Index.Php/Eduteach/Article/View/2412.

Gunadi, R.A.A. 2014. Evaluasi Pembelajaran Aktif Kreatif Efektif Dan Menyenangkan Dengan Model Context Input Process Product. Jurnal Ilmiah WIDYA, 2(2), 1-8. Https://EJournal.Jurwidyakop3.Com/Index.Php/Jurnal-Ilmiah/Article/View/168.

Gunawan, I. 2011. Evaluasi Program Pembelajaran. Jurnal Pendidikan, 17(1). Journal.Unipma.Ac.Id/Index.Php/JP/Article/View/108.

Hasan, S.H. 2004. Implementasi Kurikulum Dan Guru. Inovasi Kurikulum, 1(1), 1-9. Https://Ejournal.Upi.Edu/Index.Php/JIK/Article/View/35593.

Hasan, S.H. 2013. History Education In Curriculum 2013: A New Approach To Teaching History. Historia: Jurnal Pendidik Dan Peneliti Sejarah, 14(1), 163-178. Https://Ejournal.Upi.Edu/Index.Php/Historia/Article/View/2023.

Hidayat, S. 2013. Pengembangan Kurikulum Baru. Bandung: PT. Remaja Rosdakarya. 
1297 Komponen-komponen Kurikulum Sekolah Dasar-Elfin Nazri, Azmar, Neliwati DOI: https://doi.org/10.31004/edukatif.v4i1.2160

Kuswandi, A. 2011. Desentralisasi Pendidikan Dalam Penyelenggaraan Otonomi Daerah Di Indonesia. Governance, 2(1), 69-98. Https://Jurnal.Unismabekasi.Ac.Id/Index.Php/Governance/Article/View/718.

Mansur, R. 2016. Pengembangan Kurikulum Pendidikan Agama Islam Multikultural: Suatu Prinsip-Prinsip Pengembangan. Vicratina: Jurnal Pendidikan Http://Riset.Unisma.Ac.Id/Index.Php/Fai/Article/View/165.

Marliana, M., \& Hikmah, N. 2013. Pendidikan Berbasis Muatan Lokal Sebagai Sub Komponen Kurikulum. Dinamika Ilmu: Jurnal Pendidikan, 13(1). Samarinda.Ac.Id/Index.Php/Dinamika Ilmu/Article/View/68.

Mimin, E. 2021. Pengembangan Model Kurikulum PAUD 2013 Berbasis Kearifan Lokal Suku Ngalum OK. Jurnal Obsesi: Jurnal Pendidikan Anak Usia Dini, 6(1), 374-388. Https://Www.Obsesi.Or.Id/Index.Php/Obsesi/Article/View/1327.

Muslimin, N. 2016. Inovasi Kurikulum Dalam Upaya Meningkatkan Mutu Pendidikan: Studi Multi Kasus Di Mtsn Watulimo. Ta'allum: Jurnal Pendidikan Islam, 4(1), 43-61. Http://Ejournal.IainTulungagung.Ac.Id/Index.Php/Taalum/Article/View/365.

Muzdalifah, T. 2020. Pengaruh Kegiatan Ko-Kurikuler Pendidikan Agama Islam Terhadap Prestasi Belajar Pendidikan Agama Islam SMK Palebon Semarang. Disertasi, Universitas Islam Sultan Agung Semarang. Http://Repository.Unissula.Ac.Id/Id/Eprint/18090.

Nidawati, N. 2021. Hakikat Kurikulum Pendidikan Islam. Jurnal Mudarrisuna: Media Kajian Pendidikan Agama Islam, 11(1), 22-42. Raniry.Ac.Id/Index.Php/Mudarrisuna/Article/View/8427.

Nuraini, L. 2019. Integrasi Nilai Kearifan Lokal Dalam Pembelajaran Matematika SD/MI Kurikulum 2013. $\begin{array}{llll}\text { Jurnal Pendidikan } & \text { Matematika } & \text { (Kudus), }\end{array}$ Http://Journal.Iainkudus.Ac.Id/Index.Php/Jmtk/Article/View/4873.

Rasyidi, M. 2019. Inovasi Kurikulum Di Madrasah Aliyah. Al Qalam: Jurnal Ilmiah Keagamaan Dan Kemasyarakatan, 33-50. Https://Jurnal.Stiq-Amuntai.Ac.Id/Index.Php/Al-Qalam/Article/View/106.

Sidik, F. 2020. Hakikat Kurikulum Dan Materi Dalam Pendidikan Islam. Jurnal Pendidikan Islam Al-Ilmi , 3(2). Http://Lonsuit.Unismuhluwuk.Ac.Id/Index.Php/Ilmi/Article/View/547.

Suardipa, I.P., \& Primayana, K.H. 2020. Peran Desain Evaluasi Pembelajaran Untuk Meningkatkan Kualitas Pembelajaran. Widyacarya: Jurnal Pendidikan, Agama Dan Budaya, 4(2), 88-100. Http://Jurnal.Stahnmpukuturan.Ac.Id/Index.Php/Widyacarya/Article/View/796/0.

Subhi, T.A. 2016. Konsep Dasar, Komponen, Dan Filosofi Kurikulum PAI. Qathruna, 3(1), 117-134. Http://Jurnal.Uinbanten.Ac.Id/Index.Php/Qathruna/Article/View/16.

Sudrajat, T., Et.Al. 2020. Inovasi Kurikulum Dan Pembelajaran Pada Masa Pandemi Covid-19. Jurnal Ilmiah Wahana Pendidikan, 6(3), 339-347. Http://Jurnal.Peneliti.Net/Index.Php/JIWP/Article/View/346.

Suhanda, A., \& Budiningsih, A. 2013. Perencanaan Kurikulum Di SMP Negeri 3 Singkawang. Jurnal $\begin{array}{llll}\text { Akuntabilitas } \quad \text { Manajemen } & \text { Pendidikan, } & \text { 1(2), }\end{array}$ Https://Journal.Uny.Ac.Id/Index.Php/Jamp/Article/View/2393.

Suja, I.W. 2017. Integrasi Kearifan Lokal Ke Dalam Kurikulum Ilmu Alamiah Dasar. Wahana Matematika Dan Sains: Jurnal Matematika, Sains, Dan Pembelajarannya, 11(1), 77-93. Https://Ejournal.Undiksha.Ac.Id/Index.Php/JPM/Article/View/11847.

Sujatmoko, E. 2016. Hak Warga Negara Dalam Memperoleh Pendidikan. Jurnal Konstitusi, 7(1), 181-212. Http://Consrev.Mkri.Id/Index.Php/Jk/Article/View/208.

Syauqi, A. 2009. Analisa Implementasi Pasal 31 Ayat 4 UUD 1945 Tentang Pemenuhan Anggaran Pendidikan 20 Persen. Disertasi, Universitas Gadjah Mada. Http://Etd.Repository.Ugm.Ac.Id/Home/Detail_Pencarian/41110. 
1298 Komponen-komponen Kurikulum Sekolah Dasar-Elfin Nazri, Azmar, Neliwati

DOI: https://doi.org/10.31004/edukatif.v4i1.2160

Trianingsih, R. 2016. Pengantar Praktik Mendidik Anak Usia Sekolah Dasar. Al Ibtida: Jurnal Pendidikan Guru MI, 3(2), 197-211. Https://Www.Researchgate.Net/Profile/RimaTrianingsih/Publication/323453950 JOURNAL AL IBTIDA 3 2 2 197-

211_PENGANTAR_PRAKTIK_MENDIDIK_ANAK_USIA_SEKOLAH_DASAR/Links/5a96b51fa6f dccecff0a324e/JOURNAL-AL-IBTIDA-3-2-197-211-PENGANTAR-PRAKTIK-MENDIDIK-ANAKUSIA-SEKOLAH-DASAR.Pdf. 